\title{
Is contact allergy to preservatives, antioxidants and fragrances an additional factor influencing the treatment rosacea?
}

\section{Czy alergia na konserwanty, przeciwutleniacze i substancje zapachowe stanowi dodatkowy czynnik utrudniający leczenie trądziku różowatego?}

\author{
Ewa Chlebus', Marcin Chlebus², Andrzej Szmurło', Kajetan Dąbrowa \\ 'NZOZ Novaderm, Warsaw, Poland \\ 2Department of Quantitative Finance, Faculty of Economic Sciences, University of Warsaw, Poland \\ ${ }^{3}$ Institute of Organic Chemistry, Polish Academy of Sciences, Warsaw, Poland
}

'NZOZ Novaderm, Warszawa, Polska

2Zakład Finansów llościowych, Wydział Nauk Ekonomicznych, Uniwersytet Warszawski, Polska

${ }^{3}$ Instytut Chemii Organicznej, Polska Akademia Nauk, Warszawa, Polska

\section{CORRESPONDING AUTHOR/} ADRES DO KORESPONDENCJI: dr n. med. Ewa M. Chlebus NZOZ Novaderm

Warszawa

e-mail: drchlebus@drchlebus.pl

\begin{abstract}
Introduction: Topical treatment and daily skin care are the biggest challenges in the treatment of rosacea. The treatment is long lasting and particularly difficult because of poor tolerance to skin care products.

Objective: A search for factors that can influence the progress of rosacea among contact allergens, and to find out why are some patients resistant to the therapy. A detailed analysis involved fragrances, antioxidants and preservatives.
\end{abstract}

Material and methods: Patients with complicated rosacea were tested for contact allergies. The testing was performed between 2010 and 2017 in a group of 269 patients. The patients were divided into two groups: tested before and tested after 2014. The reason for this division was a different distribution of positive tests for certain allergens before and after 2014.

Results: $62.8 \%$ of patients had erythematotelangiectatic rosacea (ETR), $15.6 \%$ had papulo-pustular rosacea (PPR), 21.6\% had both ETR and PPR. Among fragrances, the fragrance mix and balsam of Peru most frequently gave the positive result. After 2014, among phenolic antioxidants a positive reaction to dodecyl gallate increased from $5.6 \%$ to $20.0 \%$ in the first reading, and from $12.7 \%$ to $46.4 \%$ in the second reading. High proportion of positive results were seen for octyl gallate and paraben mix. For preservatives, positive reactions were recorded for $0.02 \%$ water solution of methylisothiazolinone (MIT) and methylchloroisothiazolinone (MCI), benzyl alcohol and phenoxyethanol. After 2014, reaction caused by propolis was observed.

Conclusions: In treatment-resistant cases of rosacea, standard procedures should include testing for contact allergens. The first and the second reading are equally important for the further therapy. 


\section{STRESZCZENIE}

Wprowadzenie: Największym wyzwaniem w prowadzeniu pacjenta z trądzikiem różowatym (rosacea) jest leczenie zewnętrzne i pielęgnacja skóry. Leczenie jest długotrwałe i trudne ze względu na bardzo często złą tolerancję stosowanych środków pielęgnacyjnych.

Cel pracy: Poszukiwanie wśród alergenów kontaktowych czynników, które mogą wpłynąć na nasilenie objawów rosacea i brak powodzenia terapeutycznego. Szczegółową analizę przeprowadzono dla zapachów, przeciwutleniaczy oraz konserwantów.

Materiał i metody: Przeanalizowano pacjentów z powikłanym trądzikiem różowatym, $\mathrm{u}$ których wykonano testy kontaktowe. Badania prowadzono w latach 2010-2017 w grupie 269 osób. Badanych podzielono na dwie grupy w zależności od tego, czy mieli wykonane testy przed czy po 2014 roku. Podział ten wynikał z obserwacji istotnych zmian w udziale dodatnich wyników dla niektórych alergenów.

Wyniki: U 62,8\% pacjentów stwierdzono trądzik różowaty w odmianie naczyniowej (erythematotelangiectatic rosacea - ETR), u 15,6\% w odmianie grudkowo-krostkowej (papulo-pustular rosacea - PPR), a u 21,6\% jednocześnie ETR i PPR. W grupie alergenów zapachowych odczyn dodatni najczęściej uzyskiwano dla mieszanki zapachowej I oraz balsamu peruwiańskiego. W grupie przeciwutleniaczy fenolowych zaobserwowano bardzo duży wzrost odsetka pacjentów z wynikiem dodatnim po 2014 roku dla galusanu dodecylu - w pierwszym odczycie z 5,6\% do 20,0\% oraz w drugim odczycie z $12,7 \%$ do $46,4 \%$. Wysokie wyniki uzyskano również dla galusanu oktylu oraz mieszanki parabenów, w grupie konserwantów dla 0,02\% wodnej mieszaniny MIT i MCI, alkoholu benzylowego i fenoksyetanolu. Po 2014 roku u pacjentów zaczęto obserwować dodatnie odczyny dla propolisu.

Wnioski: U pacjentów z opornym na leczenie trądzikiem różowatym do standardu postępowania powinny zostać włączone kontaktowe testy alergiczne. $\mathrm{Z}$ punktu widzenia stosowanych terapii równie ważna jest ocena pierwszego i drugiego odczytu.

Key words: rosacea, contact allergy, hypersensitive skin, antioxidants, preservatives, fragrances.

Słowa kluczowe: trądzik różowaty, alergia kontaktowa, skóra wrażliwa, przeciwutleniacze, konserwanty, zapachy.

\section{INTRODUCTION}

Rosacea is a common chronic skin disease [1]. The diagnosis is based on clinical symptoms, as there is no single criterion for it. Most likely, rosacea is not a homogeneous disease, but it depends on many overlapping and mutually reinforcing factors. An important role is played by: the vascular platform (on its base - in the skin - inflammation develops in people with impaired natural immune response [2]), genetic factors, hormonal play and external factors, including: weather conditions (temperature fluctuations, sun, wind), consumed food (spices, wine), as well as hygienic and cosmetic factors (soaps and cosmetics used for facial care) [1, 3-6]. Hypersensitive

\section{WPROWADZENIE}

Trądzik różowaty (rosacea) to często występująca choroba przewlekła skóry [1]. Rozpoznanie ustala się na podstawie objawów klinicznych, ponieważ brakuje jednego kryterium wskazującego na obecność choroby. Najprawdopodobniej trądzik różowaty nie jest jednorodną jednostką chorobową, ale zależy od wielu czynników nakładających się na siebie i wzajemnie wzmacniających. Istotną rolę odgrywają: naczynia krwionośne (na ich podłożu - w skórze - rozwija się stan zapalny u ludzi z zaburzoną naturalną odpowiedzią immunologiczną [2]), uwarunkowania genetyczne, hormonalne oraz czynniki zewnętrzne, do których można zaliczyć: warunki atmosferyczne (wahania temperatury, słońce, wiatr), spoży- 
skin that occurs frequently in patients is an additional element [7].

Rosacea is a dermatological condition difficult to treat because of its tendency to relapse. Therefore, a dermatologist has not only to choose the right drug therapy and recommend an appropriate skin care, but also to discuss in detail factors that affect the patient's course of the disease. Importantly, these factors may trigger subsequent relapses. Poorly treated rosacea is a cause of frustration or even depression $[4,5,8]$.

Such serious potential effects have made rosacea an important clinical issue in the $21^{\text {st }}$ century. Three publications have played a key role in understanding of the disease and have contributed to a better understanding of etiopathogenesis and the development of more effective treatments. The first of these is the paper of 2002, in which a team of experts dealing with rosacea announced a new clinical classification of the disease and associated different treatment approaches [3]. The second work of 2007 described the role of the antibacterial cathelicidin peptide and its kallikrein- 5 activator that elicit an enhanced immune response and have been shown to play the role in the etiopathogenesis of rosacea [9]. The third one is a breakthrough report of 2011 in which the Rosacea International Expert Group (ROSIE) suggested the patient care composed of three aspects. This care includes: treatment (pharmaco- and physical therapy), skin care with dermocosmetics and patient education taking into account the psychological and social aspects of the disease [4].

The new approach to the disease has allowed to systematize data on its treatment. By the latest standards, the therapeutic process usually begins with oral medications. In the treatment of rosacea, oral medications: tetracyclines [10], macrolide antibiotics $[11,12]$ and isotretinoin $[13,14]$, and topical: metronidazole [15, 16], azelaic acid [17] and ivermectin [18] play the most important role. Oral treatment works well in the treatment of papular lesions and pustules, but has minimal effect on erythema and telangiectasia [4]. However, the biggest challenge in managing a patient with rosacea is the external treatment and skin care. It is long-lasting and particularly difficult, because of widespread poor tolerance to skin care agents used [19]. In the face of the COVID-19 coronavirus pandemic, which began at the end of 2019 and required people to use disinfectants and soaps more often, it was particularly important to look at substances contained in these preparations. Information on which substances of those contained in disinfectants and soaps are particularly poorly tolerated by patients will be available after collecting the research material in 2020-2021. This does not change the fact that a better understanding of the vulnerability of wane pokarmy (przyprawy, wino) oraz czynniki higieniczne i kosmetyczne (mydła i kosmetyki stosowane do pielęgnacji twarzy) [1,3-6]. Elementem dodatkowym jest często występująca u pacjentów nadwrażliwość skóry hypersensitive skin [7].

Rosacea to jednostka dermatologiczna trudna do leczenia ze względu na skłonność do nawrotów. W związku z tym zadaniem dermatologa jest nie tylko wybranie odpowiedniej terapii farmakologicznej i zalecenie pacjentowi właściwej pielęgnacji skóry, lecz także dokładne omówienie czynników, które wpływają na przebieg choroby i mogą wyzwalać kolejne nawroty. Źle leczony trądzik różowaty jest powodem frustracji, a nawet depresji $[4,5,8]$.

Tak poważne potencjalne skutki spowodowały, że trądzik różowaty stał się istotnym zagadnieniem klinicznym w XXI wieku. Kluczową rolę w rozumieniu tej choroby odegrały trzy publikacje, które przyczyniły się do lepszego zrozumienia etiopatogenezy oraz opracowania bardziej skutecznych sposobów leczenia. Pierwszą z nich jest praca z 2002 roku, w której zespół ekspertów zajmujących się trądzikiem różowatym ogłosił nowy podział kliniczny tego schorzenia i odpowiednie metody leczenia [3] W drugiej pracy z 2007 roku opisano rolę przeciwbakteryjnego peptydu katelicydyny i jego aktywatora kalikreiny 5, które wywołują nasiloną odpowiedź immunologiczną, oraz wykazano ich znaczenie w etiopatogenezie rosacea [9]. Trzecia publikacja to przełomowa praca z 2011 roku, w której grupa międzynarodowych ekspertów Rosacea International Expert Group (ROSIE) zaproponowała trzyelementową opiekę nad pacjentami. Opieka ta obejmuje: leczenie (farmakoterapię i fizykoterapię), pielęgnację skóry dermokosmetykami oraz edukację pacjenta $\mathrm{z}$ uwzględnieniem psychicznych i społecznych aspektów choroby [4].

Nowe podejście do choroby pozwoliło usystematyzować dane na temat jej leczenia. Według najnowszych standardów terapię zazwyczaj zaczyna się od leków doustnych. W leczeniu trądziku różowatego największą rolę odgrywają leki doustne: tetracykliny [10], antybiotyki makrolidowe [11, 12] i izotretynoina [13, 14], oraz miejscowe: metronidazol $[15,16]$, kwas azelainowy [17] i iwermektyna [18]. Leczenie doustne sprawdza się w przypadku zmian grudkowych i krostek, ma natomiast minimalny wpływ na rumień i teleangiektazje [4]. Największym wyzwaniem jest jednak leczenie zewnętrzne i pielęgnacja skóry. Jest ono długotrwałe i szczególnie trudne ze względu na powszechnie występującą złą tolerancję stosowanych środków do pielęgnacji skóry [19]. W obliczu pandemii COVID-19, która rozpoczęła się pod koniec 2019 roku i spowodowała dużo częstsze stosowanie środków odkażających i mydeł, szczególnie ważne stało się zwracanie uwagi na skład tych preparatów. Informacje, które substancje zawarte w środkach odkażających i mydłach są szczególnie źle tolerowane przez pacjentów, będzie można uzyskać po 
particularly sensitive patients to sensitization and irritation by fragrances, antioxidants and preservatives can help in the proper determination of the treatment and care process (elimination of the most commonly irritating and allergenic ingredients) even with such widespread change of care habits in the society.

\section{OBJECTIVE}

Phenomena triggering uncontrolled relapses make treatment of patients with rosacea difficult, long and expensive in practice. It should also be remembered that in many patients this disease causes psychosocial problems, which further emphasizes the importance of the search.

Long-term clinical observations drew our attention to groups of patients with a difficult and atypical form of rosacea, who, in addition to changes typical for the disease, were also characterized by other severe skin lesions or lack of response to the treatment used.

The presentation of skin lesions in the examined patients suggested that cosmetics used by the patients played an important role in the severity of rosacea and increased difficulty in its treatment.

For some time, difficulties have been observed in obtaining the expected improvement, as if new additional factors were present that impeded the treatment process. Our attention was drawn to the fact that patients often reported exceptional skin hypersensitivity and lack of tolerance to almost all commonly available ointments and creams, including those that apparently did not contain any irritating ingredients. For this reason, the decision was made to perform contact tests in selected patients, with particular emphasis on antioxidants, preservatives and fragrance substances that might exert a potential skin sensitizing or irritating effect.

The purpose of this study was to look for factors that can affect the severity of rosacea symptoms and which, if avoided, can shorten or facilitate rosacea treatment.

\section{MATERIAL AND METHODS}

The study material consisted of patients with complicated erythematotelangiectatic rosacea (ETR) and papulo-pustular rosacea (PPR) in whom contact tests for basic or cosmetic allergens were done. The study was conducted in 2010-2017 on a group of 269 patients. Among the patients tested, 164 were tested for basic and cosmetic allergens, 86 for basic allergens only, and 19 for cosmetic allergens only. Initially, cosmetic tests had not been done in all patients, but the practice demonstrated a need for more extensive zebraniu materiału badawczego z lat 2020-2021. Nie zmienia to faktu, że lepsze zrozumienie podatności szczególnie wrażliwych pacjentów na uczulenie i podrażnienie przez substancje zapachowe, przeciwutleniające oraz konserwujące może pomóc we właściwym ustalaniu procesu leczenia i pielęgnacji (eliminacji najczęściej drażniących i alergizujących składników) nawet przy tak powszechnej zmianie nawyków pielęgnacyjnych w społeczeństwie.

\section{CEL PRACY}

Zjawiska wyzwalające niekontrolowane nawroty choroby powodują, że leczenie pacjentów z trądzikiem różowatym w praktyce jest trudne, długotrwałe i kosztowne. Należy także pamiętać, że u wielu osób choroba ta wywołuje problemy psychospołeczne, co dodatkowo podkreśla znaczenie badań w tym zakresie.

Wieloletnie obserwacje kliniczne zwróciły naszą uwagę na grupy pacjentów z trudną i nietypową postacią rosacea, którzy poza zmianami charakterystycznymi dla tej choroby mieli również inne nasilone zmiany skórne lub nie odpowiadali na stosowane leczenie.

Obraz zmian skórnych u badanych pacjentów sugerował, że stosowane kosmetyki mają istotny wpływ na nasilenie rosacea i trudności w leczeniu.

Od pewnego czasu zaobserwowano trudności z uzyskaniem przewidywanej poprawy, tak jakby zaistniały nowe, dodatkowe czynniki utrudniające proces leczenia. Naszą uwagę zwróciło to, że często chorzy zgłaszali wyjątkową nadwrażliwość skóry i brak tolerancji na prawie wszystkie powszechnie dostępne maści i kremy, również te, które pozornie nie zawierają żadnych składników drażniących. Z tego względu u wybranych pacjentów postanowiono wykonać testy kontaktowe, ze szczególnym uwzględnieniem substancji przeciwutleniających, konserwujących i zapachowych, które mogą mieć potencjalne działanie uczulające lub drażniące skórę.

Celem badania było poszukiwanie wśród alergenów kontaktowych czynników, które mogą wpłynąć na nasilenie objawów rosacea i których unikanie może spowodować skrócenie trwania choroby lub ułatwić jej leczenie.

\section{MATERIAŁ I METODY}

Badaniem retrospektywnym objęto pacjentów $\mathrm{z}$ powikłanym trądzikiem różowatym w odmianach naczyniowej (erythematotelangiectatic rosacea - ETR) i grudkowo-krostkowej (papulo-pustular rosacea - PPR), u których wykonano testy kontaktowe $\mathrm{z}$ alergenami podstawowymi lub kosmetycznymi. Badania przeprowadzono w latach 2010-2017 w grupie 269 chorych. Wśród osób poddanych testom u 164 wykonano testy na alergeny podstawowe i kosmetyczne, u 86 tylko na alergeny podstawowe, a u 19 tylko na alergeny kosmetyczne. Początkowo tylko u części pacjentów przepro- 
testing of contact allergies, and therefore, over time, the scope of tests was extended to both standards. In the paper we present results of contact tests for fragrances, antioxidants and preservatives. The full range of analyzed allergens from these two groups is presented in the results.

Rosacea was diagnosed based on standard clinical criteria for determination of rosacea. Patients in whom the diagnosis and treatment were long and difficult were analyzed. The following four criteria have been identified for qualifying rosacea patients for allergy testing:

1) recurrent, severe erythema, accompanied by subjective symptoms (burning, burning, stinging or itching of the skin),

2) erythema changes atypical for rosacea that accompanied patients with previous diagnosis of typical rosacea,

3) unexpected recurrences characteristic of rosacea after the correct standard treatment,

4) long-term disease with no or with short periods of remission.

Examples of patients qualified for contact tests along with a brief description of their previous course of disease and results after elimination of irritants and sensitizers are presented in figure 1.

Tests were performed on patients whose disease lasted at least for a year. Allergy tests were ordered from the second visit. Patients were tested for 27 primary allergens (the European Standard) or for 48 cosmetic allergens (both tests included the same 3 allergens: parabens, quaternium and clioquinol; clioquinol was excluded from the new version of standard tests). Contact tests were performed on the back and read according to the procedure contained in the ESCD (European Society of Contact Dermatitis) indications [20].

Readings were taken 48 hours and 96 hours after tests. After 48 hours, the degree of skin irritation caused by allergens was assessed, and after 96 hours, a positive reaction was recognized as an allergy. The study paid attention not only to the second reading indicating a type 4 contact allergy, but also to a reading after 48 hours showing irritation by the test substance, because in our opinion both irritation and contact allergy could have a significant impact on rosacea.

Patch-test-chambers (Chemotechnique Diagnostics, Vellinga, Sweden) were used. They were glued to the patients' backs using a Chemotechnique patch with IQ-Ultimate chambers for applying allergens. The reaction to allergens was scored on a 4 -point scale $(0,+$, $++,+++)$. A score of 0 meant no reaction, + erythematous reaction, ++ follicular reaction, and +++ severe reaction with follicles. Due to the fact that results of 0 and + were dominating, for the sake of statistical wadzano testy kosmetyczne, ale praktyka wskazała na konieczność szerszego testowania alergii kontaktowych i dlatego następnie rozszerzono zakres testów do obu standardów. W pracy przedstawiono wyniki testów kontaktowych z substancjami zapachowymi, przeciwutleniaczami i konserwantami. Pełny zakres analizowanych alergenów z tych dwóch grup przedstawiono w wynikach.

Trądzik różowaty rozpoznawano na podstawie standardowych kryteriów klinicznych z wyodrębnieniem jego poszczególnych postaci. Analizowano pacjentów, u których przebieg diagnostyki oraz leczenia był długotrwały i trudny. Stosowano następujące kryteria kwalifikujące pacjentów z rosacea do wykonania testów alergicznych:

1) nawracający, nasilony rumień, któremu towarzyszą objawy subiektywne (pieczenie, palenie, kłucie lub świąd skóry);

2) nietypowy dla rosacea układ zmian rumieniowych u pacjentów z wcześniejszym rozpoznaniem typowego trądziku różowatego,

3) nieoczekiwane nawroty zmian charakterystycznych dla rosacea po prawidłowym, standardowym leczeniu,

4) długotrwała choroba $z$ krótkimi okresami remisji lub bez okresów remisji.

Przykłady pacjentów zakwalifikowanych do wykonania testów kontaktowych wraz ze skrótowym opisem wcześniejszego przebiegu choroby i rezultatów po odstawieniu substancji drażniących i uczulających przedstawiono $\mathrm{w}$ opisie ryciny 1 .

Badania wykonywano u osób, u których choroba trwała co najmniej rok. Wykonanie testów alergicznych zlecano od drugiej wizyty. U pacjentów przeprowadzono testy kontaktowe z 27 alergenami podstawowymi (Standard Europejski) lub z 49 alergenami kosmetycznymi (w obu typach testów występują te same trzy alergeny: parabeny, kwaternium i kliochinol; w nowej wersji testów standardowych wyłączono kliochinol). Testy kontaktowe wykonywano na skórze pleców i odczytywano zgodnie z procedurą zawartą we wskazaniach ESCD (European Society of Contact Dermatitis) [20].

Odczytów dokonywano po 48 godzinach oraz 96 godzinach od założenia testów. Po 48 godzinach oceniano stopień podrażnienia skóry przez badane alergeny, a po 96 godzinach dodatni odczyn rozpoznawano jako uczulenie. Zwracano uwagę nie tylko na drugi odczyt wskazujący na alergię kontaktową czwartego typu, lecz także na odczyt po 48 godzinach stwierdzający podrażnienie przez substancję badaną, ponieważ naszym zdaniem zarówno podrażnienie, jak i alergia kontaktowa mogą mieć istotny wpływ na przebieg rosacea.

Do wykonania testów zastosowano Patch-test-chambers (Chemotechnique Diagnostics, Vellinga, Szwecja), które były przyklejane do pleców pacjentów za pomocą plastra Chemotechnique z komorami IQ-Ultimate 
A

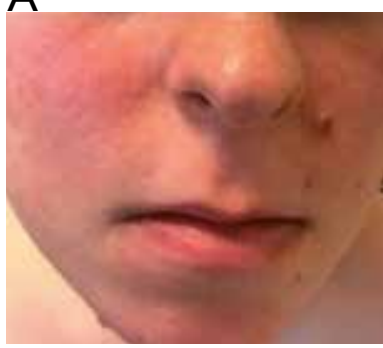

B

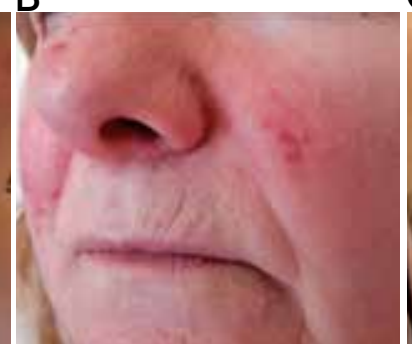

C

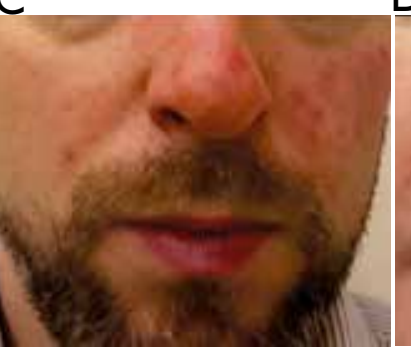

D

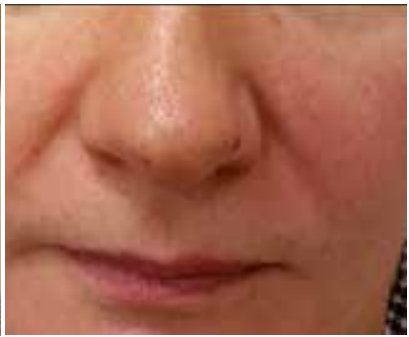

Figure I. Pictures of rosacea patients qualified for tests before the diagnosis and elimination of irritants and sensitizers. A - Patient I. Rosacea lesions have been present for a year and no progress was reported. After testing, shampoo, conditioners and washing soaps were put aside. Lesions resolved within 3 months (positive results for dodecyl gallate, balsam of Peru, phenoxyethanol). After discontinuation of irritants and sensitizers, standard rosacea treatment was initiated, resulting in remission of the disease. B - Patient 2. Rosacea has been present for 20 years. Periodic relapses were observed. Exacerbation 2 months before diagnostic tests. After testing, shampoo, conditioners and soaps were put aside. After elimination of shampoo, conditioner and soap, lesions resolved within 4 months (positive results for dodecyl gallate, odor mixture I, phenoxyethanol). After discontinuation of irritants and sensitizers, standard rosacea treatment was initiated, resulting in remission of the disease. C - Patient 3. Rosacea changes present for 2 years. After discontinuing coconut oil, face cream (a popular brand) and face cleansing gel, lesions completely disappeared within 4 months (positive results for balsam of Peru, fragrance blend I, MDBGN, dodecyl gallate). After discontinuation of irritant and allergenic substances, standard rosacea treatment was initiated, resulting in remission of the disease. D - Patient 4. Rosacea for over 9 years. After discontinuation of shampoo and conditioner, lesions resolved within 2 months (positive results for dodecyl gallate, $\mathrm{MCl}+\mathrm{MIT}$, balsam of Peru). After discontinuation of irritants and sensitizers, standard rosacea treatment was initiated, resulting in remission of the disease

Rycina I. Zdjęcia pacjentów z rosacea zakwalifikowanych do testów przed wykonaniem diagnostyki i eliminacją substancji drażniących i uczulających. A - Pacjentka I. Objawy rosacea występowały od roku i stwierdzono brak postępów w leczeniu. Po wykonaniu testów odstawiono szampon, odżywki i mydła do mycia. Zmiany ustąpily w czasie 3 miesięcy (wyniki dodatnie dla galusanu dodecylu, balsamu peruwiańskiego, fenoksyetanolu). Po odstawieniu substancji drażniących i uczulających włączono standardowe leczenie trądziku różowatego, dzięki czemu osiągnięto remisję choroby. B - Pacjentka 2. Objawy rosacea występowały od 20 lat. Obserwowano okresowe nawroty. Zaostrzenie 2 miesiące przed diagnostyką. Po wykonaniu testów odstawiono szampon, odżywki i mydła. Zmiany ustąpiły w czasie 4 miesięcy (wyniki dodatnie dla galusanu dodecylu, mieszkanki zapachowej I, fenoksyetanolu). Po odstawieniu substancji drażniących i uczulających włączono standardowe leczenie trądziku różowatego, dzięki czemu osiągnięto remisję choroby. C - Pacjent 3. Objawy rosacea od 2 lat. Po odstawieniu oleju kokosowego, kremu do twarzy (popularnej marki) oraz żelu do mycia twarzy nastąpiło całkowite ustąpienie zmian w czasie 4 miesięcy (wyniki dodatnie dla balsamu peruwiańskiego, mieszanki zapachowej l, MDBGN, galusanu dodecylu). Po odstawieniu substancji drażniących i uczulających włączono standardowe leczenie trądziku różowatego, dzięki czemu osiągnięto remisję choroby. D - Pacjentka 4. Rosacea od ponad 9 lat. Po odstawieniu szamponu i odżywki zmiany ustąpily w czasie 2 miesięcy (wyniki dodatnie dla galusanu dodecylu, MCI + MIT, balsamu peruwiańskiego). Po odstawieniu substancji drażniących i uczulających włączono standardowe leczenie trądziku różowatego, dzięki czemu osiągnięto remisję choroby

analysis the decision was made to combine all positive results into a single group. This way, a 2-point scale was used in the analysis, in which 0 meant no skin reaction and 1 meant a positive reaction.

In the statistical analysis, the distribution of features describing the study group in terms of demographics (gender, age) and specificity of the disease (rosacea subtypes, occurrence of sensitive skin, occurrence of associated diseases) was considered.

The main purpose of the study was to analyze the share of positive results in the first and second readings for each of the allergens considered. Detailed analysis was carried out for three groups of allergens: fragrances, antioxidants and preservatives.

At the beginning, the occurrence of a positive reaction for at least one allergen from the standard group and separately from the cosmetic group was analyzed, the share of positive results for the entire study group and the share of positive results between the $1^{\text {st }}$ reading and the $2^{\text {nd }}$ reading were compared.

Patients were divided into two groups, those who had tests before and after 2014. The division into groups resulted from the observation of significant do nakładania alergenów. Reakcję na alergeny opisano w 4-stopniowej skali $(0,+,++,+++)$. Wynik 0 oznaczał brak odczynu, + odczyn rumieniowy, ++ odczyn grudkowy, a +++ odczyn nasilony z powstawaniem pęcherzyków. W związku z tym, że w wynikach przeważały wartości $0 \mathrm{i}+, \mathrm{w}$ analizie statystycznej zdecydowano się połączyć wszystkie wyniki dodatnie $\mathrm{w}$ jedną grupę. $\mathrm{W}$ ten sposób $\mathrm{w}$ analizie zastosowano skalę 2-stopniową, w której 0 oznacza brak odczynu skórnego, a 1 jego występowanie.

W analizie statystycznej rozpatrzono rozkłady cech opisujących grupę badaną pod względem demograficznym (płeć, wiek) oraz specyfiki choroby (podtypy rosacea, skóra wrażliwa, choroby towarzyszące).

Głównym celem badania była analiza udziałów wyników dodatnich w pierwszym i drugim odczycie dla każdego z rozpatrywanych alergenów. Szczegółową analizę przeprowadzono dla trzech grup alergenów: substancji zapachowych, przeciwutleniaczy oraz konserwantów.

Początkowo przenalizowano występowanie odczynu dodatniego dla co najmniej jednego alergenu z grupy standardowej i oddzielnie z grupy kosmetycznej, udział 
changes in the share of people with a positive result for some allergens, in particular gallates (which was important at that time, the recommendation on the approval of propyl gallate for food use was reevaluated) [21], parabens, benzyl alcohol, 2-phenoxy ethanol and methyldibromo glutaronitrile (MDBGN) and mixtures of methylisothiazolinone (MIT) and methylchloroisothiazolinone (MCI). In the analysis, the shares of positive results (separately in the first and in the second reading) were compared between groups of patients with tests performed before and after 2014.

The ethic principles outlined in the Declaration of Helsinki an Good Clinical Practice guidelines were followed in this study.

\section{Statistical analysis}

In the study, the two-sided exact Fisher test was used to compare the variables in independent groups, and the McNemar test for paired groups. Unless otherwise indicated, the level of 0.1 was considered statistically significant. All calculations were made in R Studio Version 1.0.136 software (RStudio, Inc).

\section{RESULTS}

The study involved 269 patients, including $84.0 \%$ women and $16.0 \%$ men. The examined patients were between 19 and 81 years of age. The highest number of diagnosed patients were between 30 and 60 years old, in total $83.2 \%$ of subjects (fig. 2 A).

Analyzing individual subtypes of rosacea according to the 2002 classification [3], rosacea erythematous subtype with telangiectasia (ETR) was wyników dodatnich dla całej grupy badanej, a następnie porównano udziały wyników dodatnich między odczytem 1. i 2.

Pacjentów podzielono na dwie grupy w zależności od tego, czy mieli wykonane testy przed czy po 2014 roku. Podział ten wynikał z obserwacji istotnych zmian w udziale osób z dodatnim wynikiem dla niektórych alergenów, zwłaszcza galusanów (co istotne, $\mathrm{w}$ tym czasie ponownie oceniono rekomendację o dopuszczeniu galusanu propylu do stosowania w żywności z wynikiem pozytywnym) [21], parabenów, alkoholu benzylowego, 2-fenoksyetanolu oraz metylodibromoglutaronitrylu (MDBGN) i mieszaniny metyloizotiazoliny (MIT) i metylochlorotiazoliny (MCI). W trakcie analizy porównano udziały wyników dodatnich (osobno w pierwszym i osobno w drugim odczycie) pomiędzy grupami pacjentów z testami wykonanymi przed i po 2014 roku.

Badanie zostało przeprowadzone zgodnie z zasadami etycznymi określonymi w Deklaracji Helsińskiej i zasadami Dobrej Praktyki Klinicznej.

\section{Analiza statystyczna}

Do porównania rozkładów zmiennych dla grup niezależnych zastosowano dwustronny dokładny test Fischera, a dla grup sparowanych test McNemara. Jeżeli nie wskazano inaczej, za poziom istotności przyjęto 0,1. Wszystkie obliczenia wykonano w programie R Studio Version 1.0.136 (RStudio, Inc).

\section{WYNIKI}

W badaniu uczestniczyło 269 pacjentów, 84,0\% stanowiły kobiety i 16,0\% mężczyźni. Wiek pacjen-
A

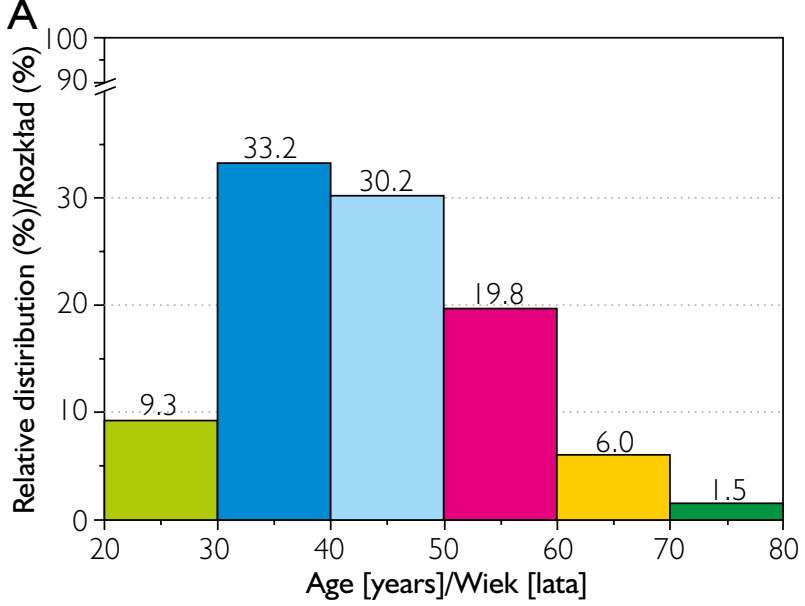

B

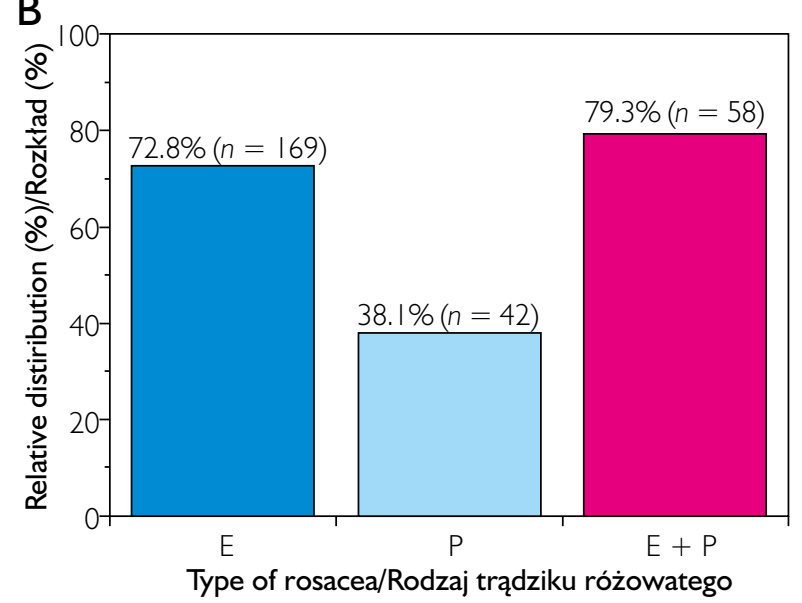

Figure 2. A - Age distribution of rosacea patients selected for patch testing. B - Symptoms of sensitive skin for a given rosacea subtype $(n=269$ patients, $p<0.000 \mathrm{I}): \mathrm{E}$ - erythematous subtype with telangiectasia (ETR), $\mathrm{P}$ - papulo-papular rosacea (PPR), E $+\mathrm{P}-$ both ETR and PPR

Rycina 2. A - Rozkład wiekowy pacjentów z trądzikiem różowatym wytypowanych do testów płatkowych. B - Objawy skóry wrażliwej u pacjentów z poszczególnymi podtypami rosacea $(n=269, p<0,000 \mathrm{I})$ : $\mathrm{E}$ - podtyp rumieniowy z teleangiektazjami (ETR), $\mathrm{P}-$ trądzik różowaty grudkowo-krostkowy (PPR), E + P - zdiagnozowano zarówno ETR, jak i PPR 
diagnosed in $62.8 \%$ of subjects, papulo-pustular form (PPR) in $15.6 \%$, and both varieties occurring throughout the disease (ETR + PPR) in 21.6\%. Sensitive skin and symptoms of sensitive skin syndrome accompanied patients with ETR in $72.8 \%$ of cases, patients with overlapping ETR and PPR in 79.3\%, and they were statistically more often present than in patients with PPR $(p<0.0001)$ : only $38.1 \%$ in this subgroup (fig. 2 B).

In addition, the study group was analyzed for the presence of other skin diseases. Patients the most often presented with seborrheic dermatitis $(16.0 \%)$, adult acne $(13.0 \%)$, hand eczema $(12.6 \%)$, and atopy was the least frequent $(0.7 \%)$.

Among patients who underwent the standard test (250 patients) in both the first and second readings, about $90 \%$ of patients had a reaction to any allergen. For patients who underwent cosmetic tests (183 patients), these ratios were slightly lower and amounted to $80.3 \%$ in the first reading and $72.7 \%$ in the second reading, respectively.

\section{Fragrances}

In recent years, patients have more and more frequently reported allergies to fragrances. Typical skin changes occurring as a result of using perfumes have been extended by skin reactions following widely used fragrances contained in soaps (for face, hands and body). In addition, fragrant shampoos, conditioners and hairsprays have become very popular. Fragrances are also often added to cosmetics dedicated to patients with rosacea.

Table 1 presents ratios of positive results in 20102013 and $2014-2017$ ( $1^{\text {st }}$ and $2^{\text {nd }}$ reading). In the group of fragrance allergens, a positive reaction was the most often observed for the fragrance mixture I and the balsam of Peru. Both are comparable in the periods under consideration. tów wynosił od 19 do 81 lat. Największą grupę stanowili pacjenci (83,2\% badanych) między 30. a 60 . rokiem życia (ryc. $2 \mathrm{~A}$ ).

Analizując poszczególne podtypy rosacea zgodnie z podziałem z 2002 roku [3], u 62,8\% badanych rozpoznano podtyp rumieniowy z teleangiektazjami (ETR), u 15,6\% postać grudkowo-krostkową (PPR), a u 21,6\% obie te odmiany występujące jednocześnie w czasie trwania choroby (ETR + PPR). Skóra wrażliwa oraz objawy sensitive skin syndrome towarzyszyły pacjentom z postacią ETR w 72,8\%, a w przypadkach nakładania ETR i PPR w 79,3\%. Były one w tych grupach statystycznie częściej obecne niż u pacjentów z PPR, u których występowały jedynie $38,1 \%$ przypadków $(p<0,0001)$ (ryc. 2 B).

W grupie badanej analizowano również występowanie innych chorób skóry. Rosacea najczęściej towarzyszyło łojotokowe zapalenie skóry $(16,0 \%)$, następnie trądzik ludzi dorosłych (13,0\%) i wyprysk rąk $(12,6 \%)$, a najrzadziej atopia $(0,7 \%)$.

U ok. $90 \%$ pacjentów, którym wykonano test standardowy (250 osób), zarówno w pierwszym, jak i drugim odczycie wykryto odczyn na przynajmniej jeden alergen. Wśród pacjentów, którym wykonano testy kosmetyczne (183 osoby), udziały te były nieco mniejsze - odpowiednio $80,3 \% \mathrm{w}$ pierwszym odczycie i $72,7 \%$ w drugim odczycie.

\section{Substancje zapachowe}

Pacjenci w ostatnim czasie coraz częściej zgłaszają $\mathrm{w}$ wywiadzie alergię na substancje zapachowe. Do typowych zmian skórnych występujących w wyniku stosowania perfum dołączyły reakcje skórne na powszechnie stosowane substancje zapachowe zawarte w mydłach (do twarzy, rąk i ciała). Ponadto bardzo popularne są pachnące szampony, odżywki i lakiery do włosów. Substancje zapachowe są często dodawane również do ko-

Table I. Comparison of allergy indices after 48 and 96 hours in patients with rosacea who underwent patch tests in 20I0-20I3 and $2014-2017$ in the group of fragrance allergens ${ }^{3}$

Tabela I. Odsetek dodatnich wyników testów kontaktowych po 48 i 96 godzinach u pacjentów z trądzikiem różowatym, u których przeprowadzono testy płatkowe w latach 2010-2013 oraz 2014-2017 w grupie alergenów zapachowycha

\begin{tabular}{|c|c|c|c|c|c|c|c|}
\hline \multirow[t]{2}{*}{$\begin{array}{l}\text { No./ } \\
\text { Lp. }\end{array}$} & \multirow[t]{2}{*}{ Allergen/Alergen } & \multicolumn{3}{|c|}{$\begin{array}{l}\text { | }{ }^{\text {st }} \text { reading, } 48 \text { hours/ } \\
\text { Pierwszy odczyt, } 48 \text { godzin }\end{array}$} & \multicolumn{3}{|c|}{$\begin{array}{l}2^{\text {nd }} \text { reading, } 96 \text { hours/ } \\
\text { Drugi odczyt, } 96 \text { godzin }\end{array}$} \\
\hline & & $2010-2013$ & $2014-2017$ & $\begin{array}{l}\text { P-value/ } \\
\text { Wartość } p\end{array}$ & $2010-2013$ & $2014-2017$ & $\begin{array}{c}\text { P-value/ } \\
\text { Wartość } p\end{array}$ \\
\hline I & Fragrance mix I/Mieszanina zapachowa I & $13.2 \%$ & $17.4 \%$ & 0.38 & $17.8 \%$ & $20.7 \%$ & 0.63 \\
\hline 2 & Balsam of Peru/Balsam peruwiański & $17.1 \%$ & $19.0 \%$ & 0.74 & $10.9 \%$ & $17.4 \%$ & 0.15 \\
\hline 3 & $\begin{array}{c}\text { Sesquiterpene lactone mix/ } \\
\text { Mieszanina laktonów seskwiterpenowych }\end{array}$ & $4.7 \%$ & $1.7 \%$ & 0.28 & $4.7 \%$ & $7.4 \%$ & 0.43 \\
\hline 4 & $\begin{array}{l}\text { 2-methoxy-6-n-pentyl-4-benzoquinone/ } \\
\text { 2-metoksy-6-n-pentyl-4-benzochinon }\end{array}$ & $3.9 \%$ & $5.0 \%$ & 0.76 & $3.1 \%$ & $5.0 \%$ & 0.53 \\
\hline
\end{tabular}

${ }^{a} p<0.1$ indicates a statistical difference between the percentage of positive results between the $1^{\text {st }}$ and $2^{\text {nd }}$ reading (two-sided test), the result reading above $5 \%$ is marked in red.

ap $<0$, I wskazuje statystyczna różnicę między odsetkami dodatnich wyników w I . i 2. odczytcie (test dwustronny), wyniki powyżej 5\% zaznaczono na czerwono. 


\section{Antioxidants}

Table 2 presents antioxidants containing a phenolic group (marked in blue in chemical structures). These compounds, due to their similar chemical structure, have an increased cross-reaction potential. Our experience shows that in a patient with clinical symptoms associated with the use of a care product containing a preservative from a particular group, only replacing it with a product containing preservatives from another group allows the therapy to succeed.

Many of these antioxidants have bactericidal properties, but their mechanism of action is often unknown. Phenolic antioxidants are commonly used as stabilizers for components susceptible to oxygen oxidation from air, e.g. oils, plant extracts, retinoids. They are most often used in creams, shampoos, hair conditioners and balms. All preservatives were analyzed for use in SARS-CoV-2 coronavirus pandemic disinfectants in 2020. Phenolic antioxidants are not commonly used in antibacterial preparations or soaps, so no increased allergic frequency is expected. For this group of preservatives a very large increase in the percentage of patients with a positive result for dodecyl gallate was observed - in the first reading from $5.6 \%$ to $20.0 \%(p<0.01)$ and in the second reading from $12.7 \%$ to as much as $46.4 \%$ $(p<0.001)$. High readings can also be seen for octyl gallate - from $15.5 \%$ to $16.8 \%(p=1.00)$ and from $11.3 \%$ to $14.4 \%(p=0.66)$ and for the paraben mix - from $8.5 \%$ to $14.0 \%(p=0.23)$ and from $9.3 \%$ to $14.9 \%(p=0.24)$, but they are not statistically significant.

\section{Preservatives}

For the analysis, preservatives were divided into two groups: group A - preservatives secreting active $\mathrm{HCHO}$ formaldehyde, and group B - a non-specific group of other preservatives with different methods of action. Cross reactions may occur in the group A due to a similar mechanism of action.

Group A preservatives are used for effective preservation of cosmetics. They have a strong bactericidal, but not very effective fungicidal effect. They are found in antibacterial gels and soaps, body and hand washing emulsions, shampoos, nail polishes, and toothpastes. They are rather safe for the human body and, apart from formaldehyde and Grotane (table 3 , items 1 and 2) - they are currently rarely used in cosmetics - they do not cause allergies. In the group of patients participating in our study, an increase in the ratio of positive results in the second reading for formaldehyde - from $2.3 \%$ to $8.3 \%(p=0.05)$ is only notable.

The market analysis during the COVID-19 pandemic indicates the use of some of these compounds smetyków przeznaczonych dla pacjentów z trądzikiem różowatym.

W tabeli 1 zestawiono udział pozytywnych wyników w latach 2010-2013 i 2014-2017 (1. i 2. odczyt). W grupie alergenów zapachowych odczyn dodatni najczęściej obserwowano dla mieszanki zapachowej I oraz balsamu peruwiańskiego. Wyniki dla obu są porównywalne w rozpatrywanych okresach.

\section{Przeciwutleniacze}

W tabeli 2 przedstawiono antyoksydanty zawierające grupę fenolową (zaznaczoną kolorem niebieskim w strukturach chemicznych). Związki te ze względu na podobną strukturę chemiczną mają zwiększony potencjał odczynów krzyżowych. Z naszych doświadczeń wynika, że u pacjenta z objawami klinicznymi związanymi ze stosowaniem środka pielęgnacyjnego z konserwantem $z$ danej grupy dopiero zastąpienie go środkiem $\mathrm{z}$ konserwantami z innej grupy umożliwia powodzenie terapii.

Wiele z tych przeciwutleniaczy ma właściwości bakteriobójcze, jednak ich mechanizm działania jest często nieznany. Antyoksydanty fenolowe stosuje się powszechnie jako stabilizatory składników podatnych na utlenienie tlenem z powietrza, takich jak oleje, ekstrakty roślinne, retinoidy. Najczęściej stosowane są w kremach, szamponach, odżywkach do włosów oraz balsamach. Wszystkie konserwanty przeanalizowano pod kątem zastosowania w środkach odkażających w okresie pandemii koronawirusa SARS-CoV-2 w 2020 roku. Antyoksydanty fenolowe nie są stosowane powszechnie $\mathrm{w}$ preparatach antybakteryjnych i mydłach, więc nie należy się spodziewać zwiększonej częstości występowania uczuleń na tę grupę. W testach z konserwantami zaobserwowano bardzo duży wzrost udziału pacjentów z wynikiem dodatnim dla galusanu dodecylu - w pierwszym odczycie z 5,6\% do 20,0\% ( $p<0,01)$ oraz $w$ drugim odczycie z 12,7\% do aż 46,4\% ( $p<0,001)$. Wysokie wyniki uzyskano również dla galusanu oktylu wzrost z $15,5 \%$ do $16,8 \%(p=1,00)$ i z $11,3 \%$ do $14,4 \%$ $(p=0,66)$ oraz dla mieszanki parabenów - wzrost z 8,5\% do $14,0 \%(p=0,23)$ oraz $z$ 9,3\% do $14,9 \%(p=0,24)$, ale różnice nie były istotne statystycznie.

\section{Konserwanty}

W analizie konserwanty podzielono na dwie grupy: grupę A - konserwanty wydzielające aktywny formaldehyd $\mathrm{HCHO}$, oraz grupę $\mathrm{B}$ - nieswoistą grupe pozostałych konserwantów o różnych mechanizmach działania. Możliwe jest występowanie odczynów krzyżowych w grupie A ze względu na podobny mechanizm działania.

Konserwanty z grupy A stosowane są do efektywnego utrwalania kosmetyków. Działają silnie bakte- 
Table 2. Comparison of allergy indices after 48 and 96 hours in patients with rosacea who underwent patch tests in 2010-2013 and 20 I 4-2017 for the group of phenol group-containing antioxidants ${ }^{\mathrm{a}}$

Tabela 2. Odsetek dodatnich wyników testów kontaktowych uczulenia po 48 i 96 godzinach u pacjentów z trądzikiem różowatym, u których przeprowadzono testy platkowe w latach 2010-2013 oraz 2014-2017 w grupie przeciwutleniaczy zawierających grupę fenolowąa

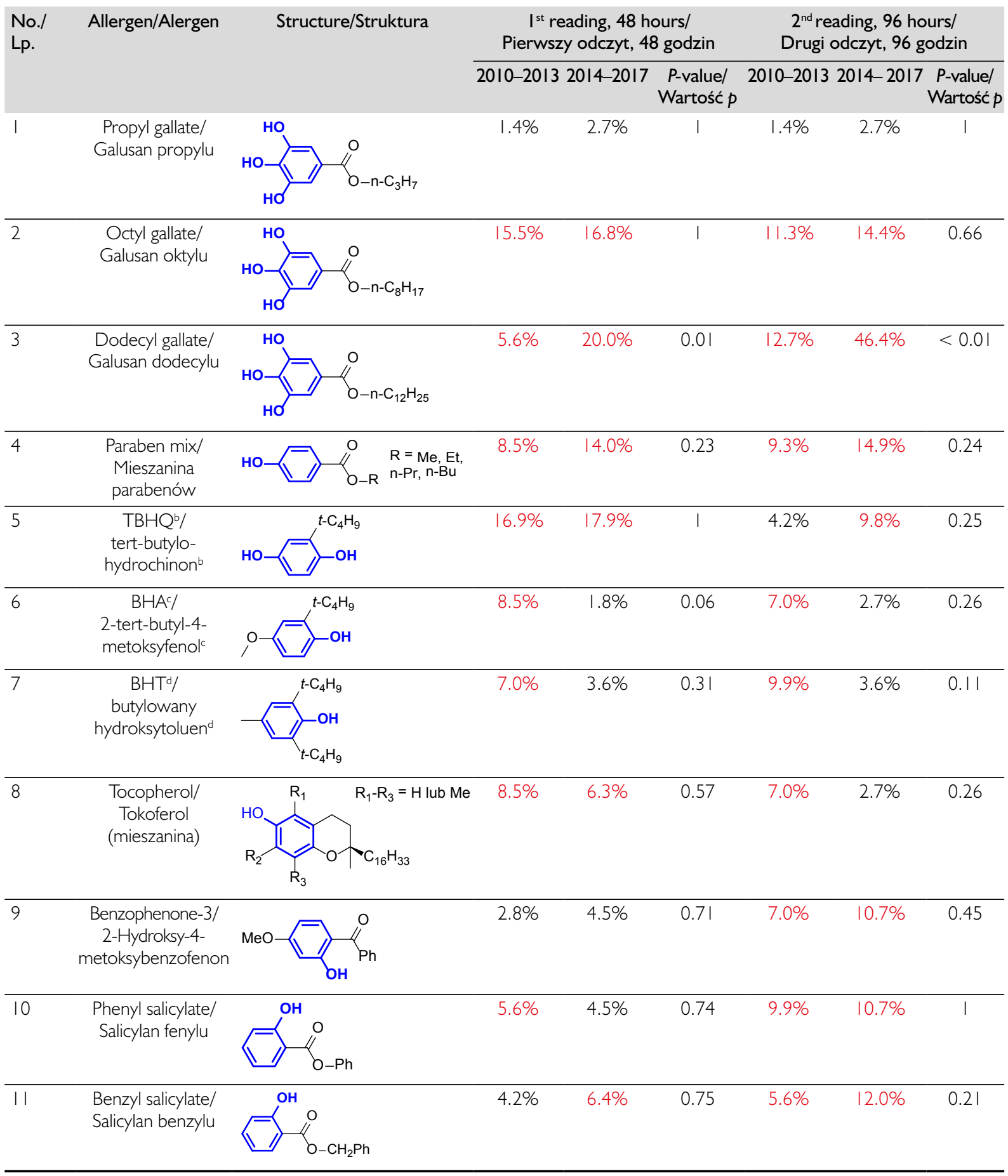

${ }^{a} p<0.1$ indicates a statistical difference between the percentages of positive results between the $1^{\text {st }}$ and $2^{\text {nd }}$ reading (two-sided test), the result reading above $5 \%$ is marked in red; phenol group colored blue; btert-Butyl hydroquinone (TBHQ); ‘2-tert-butyl-4-methoxyphenol (BHA); ${ }^{d B u t y l a t e d ~ h y d r o x y t o l u e n e ~(B H T) . ~}$ ap < 0, I wskazuje statystycznq różnicę między odsetkami dodatnich wyników w I. i 2. odczycie (test dwustronny), wyniki powyżej 5\% zaznaczono na czerwono; grupa fenolowa pokolorowana na niebiesko; 'tert-butylo-hydrochinon (TBHQ); c2-tert-butylo-4-metoksyfenol (BHA); 'butylowany hydroksytoluen (BHT). 
Table 3. Comparison of allergy indices after 48 and 96 hours in patients with rosacea who underwent patch tests in 2010-2013 and 20142017 in the group A - formaldehyde-secreting preservatives ${ }^{a}$

Tabela 3. Odsetek wyników testów kontaktowych po 48 i 96 godzinach u pacjentów z trądzikiem różowatym, u których przeprowadzono testy płatkowe w latach 20 I0-2013 oraz 2014-2017 w grupie A - konserwantów wydzielających formaldehyd ${ }^{\mathrm{a}}$

\begin{tabular}{|c|c|c|c|c|c|c|c|c|}
\hline \multirow[t]{2}{*}{$\begin{array}{l}\text { No./ } \\
\text { Lp. }\end{array}$} & \multirow[t]{2}{*}{ Allergen/Alergen } & \multirow[t]{2}{*}{ Structure/Struktura } & \multicolumn{3}{|c|}{$\begin{array}{l}\text { I st reading, } 48 \text { hours/ } \\
\text { Pierwszy odczyt, } 48 \text { godzin }\end{array}$} & \multicolumn{3}{|c|}{$\begin{array}{l}2^{\text {nd }} \text { reading, } 96 \text { hours/ } \\
\text { Drugi odczyt, } 96 \text { godzin }\end{array}$} \\
\hline & & & \multicolumn{2}{|c|}{$2010-20132014-2017$} & \multirow{2}{*}{ 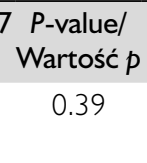 } & \multicolumn{2}{|c|}{$2010-20132014-2017$} & \multirow{2}{*}{$\begin{array}{c}\text { P-value/ } \\
\text { Wartość } p \\
0.05\end{array}$} \\
\hline I & $\begin{array}{l}\text { Formaldehyde/ } \\
\text { Formaldehyd }\end{array}$ & $\mathrm{HCHO}$ & $7.8 \%$ & $11.6 \%$ & & $2.3 \%$ & $8.3 \%$ & \\
\hline 2 & $\begin{array}{c}\text { Grotan }^{\text {b/ }} \\
\text { Heksahydro- I,3,5- } \\
\text { tris-(2-hydroksyetyl) } \\
\text { triazynab }^{\text {triand }}\end{array}$ & $\mathrm{OH}$ & $11.3 \%$ & $10.7 \%$ & I & $5.6 \%$ & $4.5 \%$ & 0.74 \\
\hline 3 & $\begin{array}{c}\text { DMDM hydantoin/ } \\
\text { I,3-bis } \\
\text { (hydroksymetylo) } \\
\text {-5,5-dimetylo- } \\
\text { imidazolidyno-2,4-dion }\end{array}$ & $\mathrm{HC}$ & $2.8 \%$ & $5.4 \%$ & 0.49 & $0.0 \%$ & $0.9 \%$ & I \\
\hline 4 & $\begin{array}{c}\text { Diazolidinyl } \\
\text { urea/N-[I,3-bis } \\
\text { (hydroksymetylo)- } \\
\text { 2,5-diokso-4- } \\
\text { imidazolidynylo]-N,N'- } \\
\text { bis(hydroksymetylo) } \\
\text { mocznik }\end{array}$ & $\mathrm{HO}-$ & $1.4 \%$ & $0.8 \%$ & I & $2.8 \%$ & $2.4 \%$ & I \\
\hline 5 & $\begin{array}{l}\text { Imidazolidinyl urea/ } \\
\text { N,N'"-metylenobis } \\
\text { [N'-[3-(hydroksyme- } \\
\text { tylo)-2,5-dioksoimi- } \\
\text { dazolidyn-4-ylo] } \\
\text { mocznik] }\end{array}$ & & $4.2 \%$ & $1.8 \%$ & 0.38 & $4.2 \%$ & $0.0 \%$ & 0.06 \\
\hline 6 & $\begin{array}{c}\text { Methenamine/ } \\
\text { Urotropina } \\
\text { (heksametyleno- } \\
\text { tetramina) }\end{array}$ & $N$ & $7.0 \%$ & $3.6 \%$ & 0.31 & $5.6 \%$ & $4.5 \%$ & 0.74 \\
\hline 7 & $\begin{array}{l}\text { Quaternium- I5c/ } \\
\text { 3-chloroallilochlorek } \\
\text { metenaminyc }\end{array}$ & $\mathrm{Cl}$ & $4.7 \%$ & $2.5 \%$ & 0.5 & $3.9 \%$ & $2.5 \%$ & 0.72 \\
\hline
\end{tabular}

${ }^{a} p<0.1$ indicates a statistical difference between the percentage of positive results between the $1{ }^{\text {st }}$ and $2^{\text {nd }}$ reading (two-sided test), the result reading above $5 \%$ is marked in red; bHexahydro- 1.3.5-tris-(2-hydroxyethyl)triazine; cl-(3-Chloroallyl)-3,5,7-triaza-I-azoniaadamantane chloride.

ap < 0, I wskazuje statystycznq różnicę między odsetkami dodatnich wyników w I. i 2. odczycie (test dwustronny), wyniki powyżej 5\% zaznaczono na czenwono;

bHexahydro- I.3.5-tris-(2-hydroxyethyl)triazine; cl-(3-Chloroallyl)-3,5,7-triaza-I-azoniaadamantane chloride.

in antibacterial preparations, but they are not widely used. We can probably expect a slight increase in post-pandemic positive reactions.

Among the other preservatives (group B - table 4) an increase in the ratio of positive results for $0.02 \%$ aqueous mixture of MIT and MCI can be seen - from $4.2 \%$ to $24.1 \%(p<0.001)$ and from $5.6 \%$ to $14.3 \%$ $(p=0.08)$ respectively, for benzyl alcohol - from $1.4 \%$ to $10.7 \%(p=0.02)$ and from $5.6 \%$ to $7.1 \%$ $(p=0.77)$, and for phenoxyethanol - from $2.8 \%$ to $8.0 \%$ $(p=0.21)$ and from $0.0 \%$ to $2.7 \%(p=0.28)$, respectively. The results for thiomersal are comparable in both groups. A significant increase of positive results in the $2^{\text {nd }}$ reading is seen for methyldibromo gluta- riobójczo, natomiast mało skutecznie grzybobójczo. Występują w żelach i mydłach antybakteryjnych, emulsjach myjących do całej skóry i rąk, szamponach, lakierach do paznokci, pastach do zębów. Są dość bezpieczne dla ludzkiego organizmu i poza formaldehydem oraz grotanem (tab. 3, poz. 1 i 2) są obecnie rzadko stosowane w kosmetykach, nie wywołują uczuleń. U pacjentów uczestniczących w naszym badaniu można jedynie zauważyć wzrost udziału wyników dodatnich w drugim odczycie dla formaldehydu - z 2,3\% do 8,3\% ( $p=0,05)$.

Analiza rynku w okresie pandemii COVID-19 wskazuje na wykorzystywanie niektórych z tych związków w preparatach antybakteryjnych, nie są 
Table 4. Comparison of allergy indices after 48 and 96 hours in patients with rosacea who underwent patch tests in $2010-2013$ and 2014-2017 in the group B - preservatives with various methods of action ${ }^{2}$

Tabela 4. Odsetek wyników testów kontaktowych po 48 i 96 godzinach u pacjentów z trądzikiem różowatym, u których przeprowadzono testy płatkowe w latach 2010-2013 oraz 2014-2017 w grupie B - konserwantów o różnych metodach działania ${ }^{\mathrm{a}}$

\begin{tabular}{|c|c|c|c|c|c|c|c|c|}
\hline \multirow[t]{2}{*}{$\begin{array}{l}\text { No./ } \\
\text { Lp. }\end{array}$} & \multirow[t]{2}{*}{ Allergen/Alergen } & \multirow[t]{2}{*}{ Structure/Struktura } & \multicolumn{3}{|c|}{$\begin{array}{l}\text { I st reading, } 48 \text { hours/ } \\
\text { Pierwszy odczyt, } 48 \text { godzin }\end{array}$} & \multicolumn{3}{|c|}{$\begin{array}{l}2^{\text {nd }} \text { reading, } 96 \text { hours/ } \\
\text { Drugi odczyt, } 96 \text { godzin }\end{array}$} \\
\hline & & & $2010-2013$ & $2014-201$ & $\begin{array}{l}\text { P-value/ } \\
\text { Wartość } p\end{array}$ & $2010-2013$ & $2014-2017$ & $\begin{array}{c}\text { P-value/ } \\
\text { Wartość } p\end{array}$ \\
\hline I & $\begin{array}{c}\text { 0.01\% MIT + MClb/ } \\
\text { 0.01\% Mieszanina } \\
\text { metylochloroizotiazolinonu } \\
\text { i metyloizotiazolinonu }\end{array}$ & & $7.8 \%$ & $9.9 \%$ & 0.66 & $0.8 \%$ & $4.1 \%$ & 0.11 \\
\hline 2 & $\begin{array}{c}\text { 0.02\% MIT }+\mathrm{MCl}^{\mathrm{b}} / \\
\text { 0.02\% Mieszanina } \\
\text { metylochloroizotiazolinonu } \\
\text { i metyloizotiazolinonu }\end{array}$ & & $4.2 \%$ & $24.1 \%$ & $<0.01$ & $5.6 \%$ & $14.3 \%$ & 0.09 \\
\hline 3 & $\begin{array}{c}\text { Benzyl alcohol/ } \\
\text { Alkohol benzylowy }\end{array}$ & & $1.4 \%$ & $10.7 \%$ & 0.02 & $5.6 \%$ & $7.1 \%$ & 0.77 \\
\hline 4 & $\begin{array}{l}\text { Phenoxyethanol/ } \\
\text { 2-Fenoksyetanol }\end{array}$ & & $2.8 \%$ & $8.0 \%$ & 0.21 & $0.0 \%$ & $2.7 \%$ & 0.28 \\
\hline 5 & $\begin{array}{c}\text { Methyldibromo glutaronitrile/ } \\
\text { I,2-Dibromo-2,4- } \\
\text { dicyjanobutan }\end{array}$ & $\|\mathbb{N}\| C$ & $5.6 \%$ & $11.2 \%$ & 0.3 & $4.2 \%$ & $12.0 \%$ & 0.08 \\
\hline 6 & $\begin{array}{c}\text { Thimerosal/ } \\
\text { Tiomersal (sól sodowa kwasu } \\
\text { 2-etylortęciotiosalicylowego) }\end{array}$ & & $14.1 \%$ & $17.0 \%$ & 0.68 & $16.9 \%$ & $15.2 \%$ & 0.84 \\
\hline 7 & Propolis/Propolis & - & $0.0 \%$ & $4.1 \%$ & 0.03 & $0.0 \%$ & $9.9 \%$ & $<0.01$ \\
\hline 8 & $\begin{array}{c}\text { Chlorhexidine digluconate/ } \\
\text { Chloroheksydyna }\end{array}$ & 2 kwas glukonowy & $9.9 \%$ & $1.8 \%$ & 0.03 & $5.6 \%$ & $0.0 \%$ & 0.02 \\
\hline 9 & $\begin{array}{l}\text { Triclosan/ } \\
\text { Triklosan (5-chloro-2-(2,4- } \\
\text { dichlorofenoksy)fenol) }\end{array}$ & 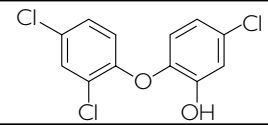 & $4.2 \%$ & $8.0 \%$ & 0.38 & $4.2 \%$ & $3.2 \%$ & 0.71 \\
\hline
\end{tabular}

a $<0.1$ indicates a statistical difference between the percentage of positive results between the 1 st and $2^{\text {nd }}$ reading (two-sided test), the result reading above $5 \%$ is marked in red; ' $\mathrm{MIT}$ - Methylisothiazolinone, $\mathrm{MCl}$ - methylchloroisothiazolinone.

${ }^{a} p<0$, I wskazuje statystyczna różnicę między odsetkami dodatnich wyników w I. i 2. odczycie (test dwustronny), wyniki powyżej 5\% zaznaczono na czerwono; ${ }^{b} \mathrm{MIT}$ - metyloizotiazolina, $\mathrm{MCl}$ - metylochlorotiazolina.

ronitrile - from $2.3 \%$ to $8.3 \%(p=0.05)$ and $4.2 \%$ to $12.0 \%$ (for $p=0.08$ ), respectively, is observed. In addition, after 2014 irritations to propolis began to appear in patients - a change from $0.0 \%$ to $4.1 \%$ in the first reading $(p=0.03)$ and from $0.0 \%$ to $9.3 \%(p<0.01)$. It is also worth noting that after 2014 the number of patients with positive reaction for chlorhexidine digluconate significantly dropped - from $9.9 \%$ to $1.8 \%$ $(p=0.03)$ and from $5.6 \%$ to $0.0 \%(p=0.02)$.

The potential for increased allergy to preservatives in the group C during and after the COVID-19 pandemic is very high, because these preservatives are very often used in antibacterial preparations. The combination of MIT and MCI, benzyl alcohol and one jednak powszechnie stosowane. Najprawdopodobniej możemy oczekiwać niewielkiego wzrostu odczynów dodatnich po pandemii.

Wśród pozostałych konserwantów (grupa B - tab. 4) można zauważyć wzrost udziału wyników dodatnich dla $0,02 \%$ wodnej mieszaniny MIT i MCI - odpowiednio z $4,2 \%$ do $24,1 \%(p<0,001)$ i z $5,6 \%$ do $14,3 \%(p=0,08)$, alkoholu benzylowego - z 1,4\% do 10,7\% ( $p=0,02)$ i z 5,6\% do $7,1 \%(p=0,77)$ oraz fenoksyetanolu - odpowiednio z 2,8\% do $8,0 \%(p=0,21)$ i z $0,0 \%$ do $2,7 \%(p=0,28)$. Wyniki dla tiomersalu są porównywalne w obu grupach. Można zauważyć również istotny wzrost udziału wyników dodatnich w drugim odczycie dla metylodibromoglutaronitrylu - odpowiednio z 2,3\% do 8,3\% ( $p=0,05)$ 
phenoxyethanol, characterized by a high allergenic and irritating factor, are used in antibacterial preparations, including gels and hand disinfectants, as well as in hygienic hand wash gels. It should be emphasized that these preservatives are not only found in antibacterial preparations, they are also found in many other care products. For example, a mixture of MIT and MCI, benzyl alcohol and phenoxyethanol is also found in shampoos and other commonly used cosmetics.

Although for chlorhexidine digluconate and triclosan a decrease in allergic reactions was observed, during and after the COVID-19 pandemic we expect a renewed increase in irritation and allergy rates, because the first of these is a component found in many disinfectant preparations both in the form of liquid, and in the form of disinfectant wipes, and the other is found in many disinfectant and antibacterial preparations.

An additional complication arises from the fact that a large proportion of disinfectants contain many of the substances listed above. In order to estimate the prevalence of individual substances in disinfectants, the number of products containing a given preservative was checked on a popular sales website and it turned out that from 50 to as much as 2000 offers may be found, depending on the preservative. Availability of products containing analyzed preservatives means that a drastic increase in irritation and allergies may be expected (table 4).

\section{DISCUSSION}

It has been pointed out in the literature that rosacea is a disease that occurs most often in the $4^{\text {th }}-5^{\text {th }}$ decade of life, especially in women, which may be associated with a decrease in estrogen levels in the menopausal period. This decrease triggers excessive expression of neurokinin-B, which translates into hot flashes and redness of the cheek skin [22]. However, in our study the largest number of patients with rosacea in the group of 30-40-year-olds was observedthere were more of these patients than those over the age of 40 [23]. This suggests existence of additional factors that mimic, trigger or overlap pre-existing vascular lesions.

Clinically, most often they were patients with erythematosus rosacea with telangiectasia (ETR). They presented a prolonged erythema and edema not only in places typical for rosacea, but also in other locations on the face: in the middle of the forehead (with clear lateral parts of the forehead), in the nasobuccal region or on the chin. The erythema could also be generalized (all over the face). Another group consisted of patients with rosacea whose exacerbated typical ETR was associated with pustulo-papular le- oraz z 4,2\% do 12,0\% $(p=0,08)$. Ponadto po 2014 roku zaczęły się pojawiać u pacjentów odczyny po propolisie zmiana z $0,0 \%$ do $4,1 \% \mathrm{w}$ pierwszym odczycie $(p=0,03)$ oraz z $0,0 \%$ do $9,3 \% \mathrm{w}$ drugim $(p<0,01)$. Warto również podkreślić, że po 2014 roku istotnie zmniejszyła się liczba pacjentów $z$ dodatnim odczynem dla diglukonianu chlorheksydyny - z 9,9\% do 1,8\% (p=0,03) oraz z 5,6\% do $0,0 \%(p=0,02)$.

Potencjał zwiększenia się alergii na konserwanty z grupy C w trakcie i po pandemii COVID-19 jest bardzo duży, ponieważ są one często stosowane w preparatach antybakteryjnych. Połączenie MIT i MCI, alkohol benzylowy oraz fenoksyetanol, charakteryzujące się dużym współczynnikiem alergizującym i drażniącym, są stosowane w preparatach antybakteryjnych, w tym żelach oraz płynach dezynfekujących do rąk, a także w higienicznych żelach do mycia rąk. Należy podkreślić, że wymienione konserwanty nie występują jedynie w preparatach antybakteryjnych, pojawiają się również $\mathrm{w}$ wielu innych środkach pielęgnacyjnych. Dla przykładu mieszanina MIT i MCI, alkohol benzylowy i fenoksyetanol występują również w szamponach i innych powszechnie stosowanych kosmetykach.

Mimo że w naszych badaniach obserwowano spadek alergizacji na diglukonian chlorheksydyny i triklosan, jednak w trakcie i po pandemii COVID-19 spodziewamy się ponownego wzrostu drażnienia i alergii, gdyż pierwszy z nich jest składnikiem wielu preparatów dezynfekujących zarówno w postaci płynu, jak i chusteczek odkażających, a drugi często występuje w preparatach odkażających i antybakteryjnych.

Dodatkową komplikacją jest to, że duża część preparatów odkażających zawiera jednocześnie kilka wymienionych wyżej substancji. W celu oszacowania powszechności występowania poszczególnych substancji w środkach odkażających sprawdzono liczby ofert produktów $\mathrm{z}$ danym konserwantem $\mathrm{w}$ popularnym portalu sprzedażowym. Okazało się, że w zależności od konserwantu można znaleźć od 50 do 2000 nowych ofert. Powszechność produktów z analizowanymi konserwantami powoduje, że należy oczekiwać drastycznego wzrostu liczby podrażnień i alergii związanych z nimi (tab. 4).

\section{OMÓWIENIE}

W piśmiennictwie wskazywano, że rosacea jest chorobą występującą najczęściej w 4. i 5. dekadzie życia, zwłaszcza u kobiet, co może mieć związek ze zmniejszeniem stężenia estrogenów w okresie okołomenopauzalnym. Spadek ten wyzwala nadmierną ekspresję neurokininy B, co przekłada się na uderzenia gorąca i zaczerwienienie skóry policzków [22]. W naszej próbie zaobserwowaliśmy jednak największą liczbę chorych w grupie wiekowej 30-40 lat - było ich więcej niż osób po 40. roku życia, u których rosacea występuje częściej [23]. 
sions (PPR). The overlapping of ETR and PPR clinical presentations was described previously [23]. The third group (the least numerous) were patients with the typical PPR form.

In the patients analyzed in this study, skin lesions merging ETR and PPR occurred mainly during exacerbations of the disease. Skin changes were often accompanied by subjective symptoms, i.e. burning, itching or flushing of the facial skin. The phenomenon of hypersensitive skin occurred mainly in people with vascular lesions, whether isolated (ETR) or mixed (ETR + PPR). Sensitive skin and symptoms of Sensitive Skin Syndrome were statistically more frequently compared to patients with PPR $(p<0.0001)$, ryc. 2 B.

Contrary to the reports of Young et al. [24] and Jappe et al. [25], we did not notice that the problem of contact allergy and irritation in rosacea concerned our group of older patients.

Positive results in contact tests in the group of examined patients were more frequent than those described in other reports concerning rosacea [25-27]. This is due to the fact that our studies were limited to the most difficult cases of rosacea both clinically and in the course of their disease. Because of their acute inflammation and/or hypersensitive skin those patients seem to be particularly predisposed to allergic contact sensitization [28].

A great deal of irritation or sensitization reactions have also been observed with perfume synthetics and balsam of Peru, a mixture of parabens, tert-butyl hydroquinone, octyl and dodecyl gallates, a mixture of MIT and MCI, thimerosal, and propolis. It should be emphasized that regardless of the percentage of positive results for a particular allergen, for a given patient allergy or irritation to any allergen can play a difficult role in the selection of appropriate cosmetics and external-use drugs.

Our long-standing practice of managing patients with rosacea shows that doubtful or weak reactions are extremely important in the diagnosis of contact allergy in this disease, and the most difficult are reactions to odors, antioxidants and preservatives. The important role of lower readings in the diagnosis of contact allergies is also confirmed by Veverka and Davis (2020). In their literature review [29] at Dermatitis this year, the authors stated that in $84 \%$ of research works on allergy tests in the standard series researchers had not considered the presence of dubious or weak reactions and had rejected them when interpreting the results. The authors noted, however, that the problem of dubious reactions was very common and should be included in the studies, as it might be relevant to the diagnosis of contact allergy.

Although, not much importance is usually attached to the reading after 48 hours in literature [20],
Sugeruje to dodatkowe czynniki, które imitują, wyzwalają lub nakładają się na już istniejące zmiany naczyniowe.

Klinicznie najczęściej byli to chorzy na rosacea z postacią rumieniową z teleangiektazjami (ETR). Występował u nich długotrwały rumień i obrzęk nie tylko $\mathrm{w}$ miejscach typowych dla rosacea, lecz także w innych lokalizacjach na twarzy: na środku czoła (z wolnymi od zmian bocznymi częściami czoła), w okolicy nosowo-policzkowej lub na brodzie. Rumień mógł być również uogólniony (na całej twarzy). Inna grupa to pacjenci $\mathrm{z}$ rosacea, u których w trakcie zaostrzenia typowej postaci ETR dołączały się zmiany rumieniowo-krostkowe (PPR). Nakładanie obrazów klinicznych ETR i PPR opisywano już wcześniej [23]. Trzecia grupa (najmniej liczna) to chorzy z typową postacią PPR.

U badanych pacjentów ETR i PPR jednocześnie występowały głównie w czasie zaostrzenia choroby. Zmianom skórnym często towarzyszyły objawy subiektywne, takie jak palenie, świąd lub pieczenie skóry twarzy. Zjawisko nadwrażliwości skóry występowało głównie u osób ze zmianami naczyniowymi - izolowanymi (ETR) czy też w postaci mieszanej (ETR + PPR). Skóra wrażliwa i objawy sensitive skin syndrome występowały statystycznie częściej niż PPR $(p<0.0001)$, ryc. 2 B.

Inaczej niż w publikacjach Younga i wsp. [24] oraz Jappe i wsp. [25] w naszej grupie nie zauważyliśmy, aby problem alergii kontaktowej i podrażnień w rosacea dotyczył starszych pacjentów.

Pozytywne wyniki w testach kontaktowych w grupie badanych pacjentów były częstsze od opisywanych w innych publikacjach dotyczących rosacea [25-27]. Wynika to z faktu, że ograniczyliśmy badania do najtrudniejszych przypadków rosacea zarówno pod względem obrazu klinicznego, jak i przebiegu choroby. Pacjenci z ostrym stanem zapalnym i/lub nadwrażliwą skórą wydają się szczególnie predysponowani do alergicznego uczulenia kontaktowego [28].

Bardzo dużo odczynów z podrażnienia lub uczulenia obserwowano również w przypadku syntetyków zapachowych i balsamu peruwiańskiego, mieszaniny parabenów, tert-butylo-hydrochinonu, galusanów oktylu i dodecylu, mieszaniny MIT i MCI, tiomersalu i propolisu. Należy podkreślić, że bez względu na udział wyników dodatnich dla konkretnego alergenu u pacjenta uczulenie lub podrażnienie na dowolny alergen może utrudniać dobór odpowiednich kosmetyków i leków zewnętrznych.

Z naszej wieloletniej praktyki prowadzenia pacjentów z rosacea wynika, że odczyny wątpliwe bądź słabo dodatnie są niezwykle ważne $w$ diagnostyce alergii kontaktowej w tej chorobie, a najtrudniejsze okazują się reakcje na substancje zapachowe, przeciwutleniacze i konserwanty. Ważną rolę słabszych odczytów w rozpoznaniu alergii kontaktowych potwierdzają również Veverka i Davis (2020). W przeglądzie piś- 
it seems to us that in the case of rosacea and hypersensitive skin this reading should be taken into account. Excessive irritation, persistence of this irritation even without its escalation and a slow resolution can be a very serious health problem for patients, even if they are not really allergic to these allergens. Especially that the repeated application of care creams containing irritants in a given patient bears the marks of a repeated open application test [30].

It is known that severe inflammation may cause a tendency for contact allergy on the face. Exposure to chronic irritation caused by eruption facilitates skin sensitization and contact dermatitis [31]. Rosacea can therefore be a nonspecific trigger that increases susceptibility to contact dermatitis [25].

The obtained results show the scale of difficulty in choosing the right cream or external-use medicine for a patient with rosacea, but also, which seems less obvious, of face and hand washing preparations (patients with extremely sensitive skin touch their faces very often). Our practice shows that the choice of shampoos and hair conditioners, which often irritate the facial skin, intensify erythema and are the reason for poor tolerance of external-use drugs and for lack of success in the treatment of rosacea, has become a real problem.

In recent years, our attention has been drawn to the fact that results of tests show a drastic increase in positive reactions for gallates (in particular for dodecyl gallate). The point of reference for us was the decision made in 2014 on the positive evaluation of propyl gallate as a food preservative [21].

Gallates belong to those substances which, despite their allergenic properties, are difficult to find in the cosmetics ingredient list (INCI, International Nomenclature of Cosmetic Ingredients), probably due to the fact that they are used to a small extent as stabilizers for other formulation ingredients (e.g. plant extracts). The results of our study indicate that over the years, the rate of positive readings for fragrances and balsam of Peru, thiomersal, parabens and octyl gallate has been slowly increasing. The use of methylisothiazolines and, in particular, of dodecyl gallate has been increasing significantly. Dodecyl gallate seems to be an interesting allergen because, regardless of the high irritating potential of this anti-rancid substance, over four-fold increase in the number of people who are truly allergic to this ingredient has been observed.

Currently, during the COVID-19 virus pandemic, it seemed very interesting to perform an analysis of preservatives found in disinfectant preparations available in the market. In the review of preservatives, we indicated those that would be used much more commonly because of a need for regular hand decontamination. Patients with sensitive skin very of- miennictwa [29] opublikowanym w tym roku w Dermatitis autorzy konstatują, że w $84 \%$ prac dotyczących testów alergicznych w serii standardowej badacze nie biorą pod uwagę odczynów wątpliwych bądź słabo dodatnich i odrzucają je podczas interpretacji wyników. Autorzy zwracają jednak uwagę, że problem wątpliwych odczynów jest bardzo częsty i powinien być uwzględniony w opracowaniach, ponieważ może być istotny z punktu widzenia rozpoznawania alergii kontaktowej.

Mimo że w piśmiennictwie [20] zazwyczaj nie uważa się za istotny odczyt po 48 godzinach, wydaje nam się, że w przypadku trądziku różowatego i skóry nadwrażliwej należy ten odczyt wziąć pod uwagę. Nadmierne podrażnienie, utrzymywanie się tego podrażnienia nawet bez jego narastania i powolne ustępowanie może stanowić dla pacjentów bardzo duży problem zdrowotny, nawet jeśli nie mają uczulenia na te alergeny. Szczególnie że wielokrotne nakładanie kremów pielęgnacyjnych zawierających substancje działające drażniąco u danego chorego nosi znamiona repeated open appllication test [30].

Znany jest fakt, że nasilony stan zapalny może powodować skłonność do występowania alergii kontaktowej na twarzy. Narażenie na przewlekłe drażnienie spowodowane wypryskiem, także z podrażnienia, ułatwia uwrażliwienie skóry i wywołanie contact dermatitis [31]. Rosacea może więc być niespecyficznym wyzwalaczem, który zwiększa podatność na contact dermatitis [25].

Uzyskane wyniki pokazują skalę trudności w prawidłowym doborze odpowiedniego kremu lub leku zewnętrznego dla pacjenta z rosacea, ale także, co wydaje się mniej oczywiste, preparatów do mycia twarzy i rąk (pacjenci ze względu na niezwykle wrażliwą skórę bardzo często dotykają twarzy). Z naszej praktyki wynika, że prawdziwym problemem stał się dobór szamponów i odżywek do włosów, które bardzo często drażnią skórę twarzy, nasilają rumień i są powodem złej tolerancji leków zewnętrznych oraz braku powodzenia leczenia rosacea.

W ostatnich latach naszą uwagę zwrócił znaczący wzrost odczynów pozytywnych na galusany (zwłaszcza galusan dodecylu). Za punkt odniesienia uznaliśmy decyzję z 2014 roku o pozytywnym wyniku ponownej oceny galusanu propylu jako konserwantu dodawanego do żywności [21].

Galusany należą do substancji, które pomimo właściwości alergizujących trudno jest znaleźć na liście składników kosmetyków (INCI, International Nomenclature of Cosmetic Ingredients) prawdopodobnie ze względu na to, że są używane w niewielkim stopniu jako stabilizatory innych składników formulacji (np. wyciągów roślinnych). Wyniki naszego badania wskazują, że od lat powoli wzrasta udział odczytów dodatnich dla substancji zapachowych i balsamu peruwiańskiego, tiomersalu, parabenów i galusanu oktylu. Znacząco rośnie udział 
ten touch their face, which is why not only face care products pose a threat to patients with rosacea but also hand care ones.

\section{CONCLUSIONS}

Results obtained in this study clearly indicate that for patients suffering from rosacea with atypical or very severe lesions, atypical course or rapid relapses, contact allergy tests should be included in the standard of care. The hypothesis that contact allergy tests should be recommended to all patients with rosacea seems justified. From the point of view of therapies used in rosacea, it is equally important to assess irritation and the occurrence of contact allergy. Therefore, the results of the $1^{\text {st }}$ and $2^{\text {nd }}$ reading should be interpreted. Without eliminating irritants or sensitizers, rosacea treatment does not bring the expected results.

The results obtained also encourage the development of a set of allergens suitable for rosacea. Patients with a severe form of rosacea (especially with the ETR subtype) could be a group whose results of allergic tests would make it possible to predict the appearance of severe irritation or contact allergy to on-demand external-use drugs and creams for sensitive and vascular skin, but also to set allergy trends for the population.

Tracking allergy changes occurring in the population over time allows following trends and detecting potentially harmful allergens. For example, since 2014, a clearly visible increase in irritation and contact allergy has been observed as a result of the use of antioxidants and preservatives. A particularly spectacular effects are associated with the use of dodecyl gallate (4-fold increase; in the $2^{\text {nd }}$ reading almost up to $50 \%$ of cases). The above data may also be very helpful after the pandemic, during which disinfectants are more often used in daily skin care.

In everyday life, it is particularly difficult to verify the list of cosmetics ingredients (INCI) in order to eliminate those containing irritating and allergenic substances. Our decade-long experience in analyzing the results of contact tests and rosacea patients indicate that a positive test results cannot always be correctly interpreted right away. Most often, however, the search for irritating and allergenic ingredients present in cosmetics used by a patient allows elimination of irritating and sensitizing substances, which results in proper treatment of the patient with rosacea.

\section{CONFLICT OF INTEREST}

The authors declare no conflict of interest. metyloizotiazolinów, zwłaszcza galusanu dodecylu. Galusan dodecylu wydaje się o tyle ciekawym alergenem, że niezależnie od wysokiego potencjału drażniącego tej substancji przeciwjełczeniowej, zaobserwowano na przestrzeni lat prawie 4-krotny wzrost liczby osób uczulonych kontaktowo na ten składnik.

Obecnie, w czasie pandemii COVID-19, bardzo interesujące wydawało się wykonanie analizy dostępnych preparatów odkażających pod kątem stosowanych w nich konserwantów. W przeglądzie konserwantów wyróżniliśmy te, których stosowanie od 2020 roku powinno być znacznie częstsze ze względu na regularne odkażania rąk. Pacjenci ze skórą wrażliwą bardzo często dotykają twarzy, dlatego nie tylko preparaty do pielęgnacji twarzy, ale także rąk stanowią zagrożenie dla osób z rosacea.

\section{WNIOSKI}

Uzyskane wyniki wyraźnie wskazują, że u chorych na rosacea $\mathrm{z}$ nietypowymi lub bardzo nasilonymi zmianami, z nietypowym przebiegiem lub szybkimi nawrotami do standardu postępowania powinny zostać włączone kontaktowe testy alergiczne. Uzasadnione wydaje się zalecenie, by kontaktowe testy alergiczne wykonywać wszystkim pacjentom z trądzikiem różowatym. Z punktu widzenia terapii stosowanych w rosacea równie ważna jest ocena drażnienia oraz występowania alergii kontaktowej. W związku z tym interpretowane powinny być wyniki pierwszego i drugiego odczytu. Bez eliminacji czynników drażniących lub uczulających leczenie rosacea nie przynosi oczekiwanych rezultatów.

Przedstawione wyniki zachęcają również do opracowania zestawu alergenów odpowiednich dla rosacea. Pacjenci z trudną postacią trądziku różowatego (szczególnie z podtypem ETR) mogliby stanowić grupę, w której wyniki testów alergicznych umożliwiałyby przewidzenie pojawienia się silnego podrażnienia lub alergii kontaktowej na tworzone leki zewnętrzne i kremy dla skóry wrażliwej i naczyniowej, ale także wyznaczać trendy uczuleń dla populacji.

Śledzenie zmian alergii $\mathrm{w}$ populacji w czasie pozwala na obserwowanie trendów i wykrycie potencjalnie szczególnie szkodliwych alergenów. Dla przykładu - od 2014 roku wyraźnie widoczny jest wzrost występowania podrażnienia i alergii kontaktowej pod wpływem przeciwutleniaczy i konserwantów, zwłaszcza galusanu dodecylu (4-krotny wzrost, w drugim odczycie prawie do $50 \%$ przypadków). Powyższe dane mogą być bardzo pomocne po pandemii, w czasie której znacznie częściej stosowane są substancje odkażające w codziennej pielęgnacji skóry. 
W codziennym życiu szczególnie trudna jest weryfikacja listy składników kosmetyków (INCI) w celu eliminacji produktów z substancjami drażniącymi i alergizującymi. Nasze niemal dziesięcioletnie doświadczenie w analizowaniu wyników testów kontaktowych pacjentów z rosacea wskazuje, że nie zawsze od razu możemy właściwie zinterpretować dodatni test. Najczęściej jednak dzięki cierpliwemu poszukiwaniu składników drażniących i alergizujących w stosowanych przez pacjenta kosmetykach udaje się nam je wyeliminować, czego rezultatem jest właściwe leczenia rosacea.

\section{KONFLIKT INTERESÓW}

Autorzy nie zgłaszają konfliktu interesów.

\section{References}

Piśmiennictwo

1. Crawford M.T., Pelle G.H., James W.D.: Rosacea I. Etiology, pathogenesis and subtype classification. J Am Acad Dermatol 2004, 51,327-341.

2. Yamasaki K., Gallo R.L.: The molecular pathology of rosacea. J Dermatol Sci 2009, 55, 77-81.

3. Wilkin J., Dahl M., Detmar M., Drake L., Feinstein A., Odom R., et al.: Standard classification of rosacea: report of the National rosacea Society Expert Comittee on the Clasification and Staging of rosacea. J Am Acad Dermatol 2002, 46, 584-587.

4. Elewski B., Draelos Z., Dreno B., Jansen T., Layton A., Picardo M.: Rosacea-global diversity and optimized outcome: proposed international consensus from the Rosacea International Expert Group. J Eur Acad Dermatol Venereol 2011, 25, 188-200.

5. Schaller M., Schöfer H., Homey B., Hofmann M., Gieler U., Lehmann P., et al.: Rosacea. Management: update on general measures and topical treatment options. J Dtsch Dermatol Ges 2016, 14 Suppl 6, 17-27.

6. Steinhoff M., Schmelz M., Schauber J.: Facial erythema of rosacea - aetiology, different pathophysiologies and treatment options. Acta Derm Venerol 2016, 96, 579-589.

7. Darlenski R., Kazandjieva J., Fluhr J.W., Maurer M., Tsankov N.: Lactic acid sting test does not differentiate between facial and generalized skin functional impairment in sensitive skin in atopic dermatitis and rosacea. J Dermatol Sci 2014, 76, 151-153.

8. Halioua B., Cribier B., Frey M., Tan J.: Feelings of stigmatization in patients with rosacea. J Eur Acad Dermatol Venoreol 2017, 31, 163-168.

9. Yamasaki K., Di Nardo A., Bardan A., Murakami M., Ohtake T., Coda A., et al.: Increased serine protease activity and cathelicidin promotes skin inflammat in rosacea. Nat Med 2007, 13, 975-980.

10. Sneddon I.B.: A clinical trial of tetracycline in rosacea. Br J Dermatol 1966, 78, 649-652.

11. Torresanie M.: Clarithromycin: a new perspective in rosacea treatment. Int J Dermatol 1998, 37, 347-349.

12. Bakar O., Demircay Z., Gurbuz O.: Therapeutic potential of azithromycin in rosacea. Int J Dermatol 2004, 43, 151-154.

13. Ertl G.A., Levine N., Kligman A.M.: A comparison of the efficacy of topical tretinoin and low-dose oral isotretinoin in rosacea. Arch Dermatol 1994, 130, 319-324

14. Pelle M.T., Crawford G.H, James W.D.: Rosacea II. Therapy. J Am Acad Dermatol 2004, 51, 499-512.

15. Nielsen P.G.: Treatment of rosacea with 1\% metronidazole cream. A double-blind study. Br J Dermatol 1983, 108, $327-332$.

16. Pye R.J., Burton J.L.: Treatment of rosacea by metronidazole. Lancet 1976, 1, 1211-1212.

17. Van Zuuren E.J., Kramer S.F., Carter B.R., Graber B.R., Federowicz Z.: Effective and evidence-based management strategies for rosacea: summary of a Cochrane systemic review. Br J Dermatol 2011, 165, 760-781.

18. Deeks E.D.: Ivermectin: a review in rosacea. Am J Clin Dermatol 2015, 16, 447-452.

19. Draelos Z.D.: Cosmeceuticals for rosacea. Clin Dermatol 2017, 35, $213-217$.

20. Johansen J.D., Aalto-Korte K., Agner T., Andersen K.E., Bircher A., Bruze M., et al.: European Society of Contact Dermatitis guideline for diagnostic patch testing - recommendations on best practice. Contact Dermatitis 2015, 73, 195-221.

21. European Food Safety Authority.: Re-evaluation of dodecyl gallate (E 312) as a food additive. EFSA J 2015, 13, 4086.

22. Dellovade T.L., Merchenthaler I.: Estrogen regulation of neurokinin B gene expression in mouse arcuatenucleus is mediated by estrogen receptor alpha. Endocrinology 2004, 145, 736-742.

23. Tan J., Berg M.: Rosacea: current state of epidemiology. J Am Acad Dermatol 2013, 69, S27-S35. 
24. Young E., Van Weelden H., Van Osch L.: Age and sex distribution of the incidence of contact sensitivity to standard allergens. Contact Dermatitis 1988, 19, 307-308.

25. Jappe U., Schafer T., Schnuch A., Uter W.: Contact allergy in patients with rosacea: clinical-based prospective epidemiology study. J Eur Acad Dermatol Venereol 2008, 22, 1208-1214.

26. Jappe U., Schnuch A., Uter W.: Rosacea and contact allergy to cosmetics and topical medicaments-retrospective analysis of multicenter surveillance data 1995-2002. Contact Dermatitis 2005, 52, 96-101.

27. Çakmak S.K., Gönül M., Kılıç A., Gül Ü.: The role of contact allergy in rosacea. J Turk Acad Dermatol 2007, 1, 71201a.

28. Kohli N., Nedorost S.: Inflamed skin predisposes to sensitization to less potent allergens. J Am Acad Dermatol 2016, 75, 312-317.e1.

29. Veverka K.K., Davis M.D.: Dubiously doubtful, an exploration of the literature concerning doubtful, macular erythema, "?+," and "+/" patch test reactions. Dermatitis 2020, 31, 36-41.

30. Nakada T., Hostynek J.J., Maibach H.I.: Use tests: ROAT (repeated open application test)/PUT (provocative use test): an overview. Contact Dermatitis 2000, 43, 1-3.

31. Smith H.R., Basketter D.A., McFadden J.P.: Irritant dermatitis, irritancy and its role in allergic contact dermatitis. Clin Exp Dermatol 2002, 27, 138-146.

Received: 12.03 .2020

Accepted: 9.06 .2020

Otrzymano: $12.03 .2020 \mathrm{r}$

Zaakceptowano: $9.06 .2020 \mathrm{r}$.

How to cite this article

Chlebus E., Chlebus M., Szmurło A., Dąbrowa K.: Is contact allergy to preservatives, antioxidants and fragrances an additional factor influencing the treatment of rosacea? Dermatol Rev/Przegl Dermatol 2020, 107, 210-227.

DOI: https://doi.org/10.5114/dr.2020.97795. 